\title{
Epidemiology of Intra-Cerebral Hemorrhage in Young Adult Patients
}

\author{
Melisa $^{1}$, Asra Al Fauzi ${ }^{2}$, Anggraini Dwi Sensusiati ${ }^{3}$
}

${ }^{1}$ Faculty of Medicine, Universitas Airlangga, Surabaya, Indonesia.

${ }^{2}$ Department of Neurosurgery, Faculty of Medicine, Universitas Airlangga/Dr. Soetomo General Hospital, Surabaya, Indonesia. ${ }^{3}$ Department of Radiology, Faculty of Medicine, Universitas Airlangga/Dr. Soetomo General Hospital, Surabaya, Indonesia.

\section{A B S T R A C T}

Introduction: This study aimed to define the CT scan imaging of young adult intracerebral hemorrhage $(\mathrm{ICH})$ patients in Dr. Soetomo General Hospital, Surabaya.

Methods: This was an observational descriptive study. The data were collected retrospectively with medical records of 18 to 45 years old $\mathrm{ICH}$ patients who were treated in Dr. Soetomo General Hospital, Surabaya between 2014 and 2017. The collected data were then presented into tables.

Results: 207 patients were identified in this study. The locations of the ICH were basal ganglia $(45.89 \%)$, lobar $(41.55 \%)$, thalamus $(10.63 \%)$, brainstem $(8.7 \%)$, cerebellum $(4.83 \%)$, and others $(3.86 \%)$. The volume of $\mathrm{ICH}$ varied from less than $30 \mathrm{cc}(66.67 \%), 30$ to $59 \mathrm{cc}(27.54 \%)$, and more than $60 \mathrm{cc}(5.8 \%)$.

Conclusion: The CT scan imaging of young adults ICH mainly had hematoma volume less than $30 \mathrm{cc}$ and was mostly located in basal ganglia area then followed by lobar area.

(c) 2020 JUXTA: Jurnal IImiah Mahasiswa Kedokteran Universitas Airlangga.

Available at https://e-journal.unair.ac.id/juxta

* Correspondence: asraalfauzi@gmail.com

JUXTA: Jurnal IImiah Mahasiswa Kedokteran Universitas Airlangga

p-ISSN: 1907-3623; e-ISSN: 2684-9453

DOI: 10.20473/juxta.V11I22020.65-68

Open access under Creative Commons Attribution-ShareAlike 4.0 International License (CC-BY-SA)

\section{ART I CLE INFO}

\section{Article history:}

Received 2 July 2020

Received in revised form 9 July 2020

Accepted 21 July 2020

\section{Keywords:}

Young adults $\mathrm{ICH}$,

CT scan imaging,

$\mathrm{ICH}$ location,

Hematoma volume. 


\section{Introduction}

Intracerebral hemorrhage $(\mathrm{ICH})$ stroke is a disorder of the neurological system that is characterized by bleeding in the brain parenchyma that is not caused by trauma. ${ }^{1}$ Incidence rate of stroke in East Java based on the data collected by Indonesian Ministry of Health is $9.1 \%$, in particular the incidence rate of stroke in Surabaya is $16.4 \% .^{2}$ The incidences of $\mathrm{ICH}$ in younger group patient ( $<45$ years old) are lower than in older one. However, ICH in young adults bears a bigger economy and social consequences. ${ }^{3}$ In the course of $\mathrm{ICH}$, there are 3 phases: early hematoma phase, hematoma expansion phase, and perihematomal edema phase. Prognosis of $\mathrm{ICH}$ patients depends on the hematoma expansion phase and the perihematomal edema phase. Hematoma expansion more than $30 \mathrm{cc}$ will increase the morbidity and mortality of $\mathrm{ICH}$. Increased hematoma volume will increase the intracranial pressure that eventually causes disturbance on the brain parenchyma around it. Increased intracranial pressure will also cause arteries and vascular rupture that will worsen the condition. ${ }^{4,5}$

$\mathrm{ICH}$ is an emergency situation that needs quick and appropriate treatment to prevent the high morbidity and mortality of the disease. There is a risk of severe neurological complication that could worsen the patient's prognosis. Therefore, early diagnosis of $\mathrm{ICH}$ especially in young adults is really important. ${ }^{6}$

Most of $\mathrm{ICH}$ symptoms are not specific enough to make the diagnosis, thus neuroimaging test is important. Neuroimaging tests such as CT scan and MRI can also be used to search for the cause of $\mathrm{ICH}$. However, CT scan is superior in emergency situations by how quick the test is and its availability. ${ }^{6}$

According to the location, $\mathrm{ICH}$ is divided into deep $\mathrm{ICH}$ and lobar ICH. Deep ICH is a condition when the bleedings happen in basal ganglia, brain stem, and also cerebellum, while bleedings that happen in cortical and subcortical area of brain lobes are called lobar $\mathrm{ICH}^{7}$

The bleeding process in $\mathrm{ICH}$ will keep expanding until 6 hours in $\mathrm{ICH}$ without coagulopathy and until 24 hours in $\mathrm{ICH}$ with coagulopathy. This expanding situation will cause the formation of edema that in turn will cause secondary neuronal injury.

Based on the previous explanation, determining the volume of hematoma is important by how large the impact is on the prognosis of $\mathrm{ICH} .4,5,7$

The study of young adults $\mathrm{ICH}$ is still rare in Indonesia and less is known about this case. Therefore, adequate knowledge about the clinical characteristic and CT scan imaging of $\mathrm{ICH}$ is needed to diagnose the case properly. ${ }^{6}$

This study aimed to define the CT scan imaging especially the location of $\mathrm{ICH}$ and also the hematoma volume of $\mathrm{ICH}$ patients between 18 and 45 years old who were treated in Dr. Soetomo General Hospital, Surabaya from 2014 to 2017.

\section{Methods}

This study was a descriptive observational study. It was conducted at Neurology and Neurosurgery Department of Dr. Soetomo General Hospital, Surabaya from September 2017 to September 2018. The ethical clearance was given by Health Research Ethics Committee of Dr. Soetomo General Hospital, Surabaya. The population of this study was all 18 to 45 years old $\mathrm{ICH}$ patients in Neurology and Neurosurgery Department of Dr. Soetomo General Hospital, Surabaya who were admitted from January $1^{\text {st }} 2014$ to December $31^{\text {st }} 2017$. In total, there were 207 patients that were included in this study.

The inclusion criteria for this study was all 18 to 45 years old ICH patients who were admitted to Neurology and Neurosurgery Department of Dr. Soetomo General Hospital, Surabaya between 2014 and 2017. The exclusion criteria for this study were all $\mathrm{ICH}$ cases that were started by ischemic stroke and if their CT-scan result could not be found in the patient's medical record.

The data for this study was obtained from the CT scan result recorded in the patient's medical record, in which the data about the location and $\mathrm{ICH}$ volume could be found. Then, the data were presented in tables.

\section{Results}

The total samples in this study were 207 young adult $\mathrm{ICH}$ patients that fulfilled the inclusion and exclusion criteria of the study. For the location of $\mathrm{ICH}$, it was classified into 6 groups which were lobar, basal ganglia, thalamus, brainstem, cerebellum, and others. For hematoma volume, it was divided into 3 groups which were less than $30 \mathrm{cc}, 30$ to $59 \mathrm{cc}$ and more than $60 \mathrm{cc}$.

Table 1. Distribution of hematoma volume in young adults $\mathrm{ICH}$.

\begin{tabular}{ccc}
$\begin{array}{c}\text { Hematoma } \\
\text { volume (cc) }\end{array}$ & $\begin{array}{c}\text { All } \\
(\mathbf{n = 2 0 7 )}\end{array}$ & Percentage (\%) \\
\hline 30 & 138 & 66.67 \\
$30-59$ & 57 & 27.54 \\
$\geq 60$ & 12 & 5.80 \\
\hline
\end{tabular}

Source: Research data, processed

Table 2. Distribution of hemorrhagic location in young adults $\mathrm{ICH}$.

\begin{tabular}{lcc}
\hline Location & $\mathbf{N}$ & Percentage (\%) \\
\hline Basal ganglia & 95 & 45.89 \\
Lobar & 86 & 41.55 \\
$\quad$ Parietal & 54 & 62.79 \\
Temporal & 47 & 54.65 \\
Frontal & 23 & 26.74 \\
Occipital & 9 & 10.47 \\
Thalamus & 22 & 10.63 \\
Brainstem & 18 & 8.70 \\
Cerebellum & 10 & 4.83 \\
Other & 8 & 3.86 \\
\hline
\end{tabular}

Source: Research data, processed

Table 3. Hemorrhage location distribution of young adult $\mathrm{ICH}$ patients based on age. 


\begin{tabular}{cccc}
\hline $\begin{array}{c}\text { Age } \\
\text { (years) }\end{array}$ & Location & N & $\begin{array}{c}\text { Percentage } \\
\text { (\%) }\end{array}$ \\
\hline $18-25$ & Lobar & 12 & 85.71 \\
& Basal ganglia & 2 & 14.29 \\
& Cerebellum & 1 & 7.14 \\
& Others & 1 & 7.14 \\
& Brainstem & 0 & 0 \\
& Thalamus & 0 & 0 \\
\hline $26-35$ & Lobar & 14 & 48.28 \\
& Basal ganglia & 10 & 34.48 \\
& Brainstem & 3 & 10.34 \\
& Others & 3 & 10.34 \\
& Cerebellum & 1 & 3.45 \\
& Thalamus & 1 & 3.45 \\
\hline $36-45$ & Basal ganglia & 83 & 50.61 \\
& Lobar & 60 & 36.59 \\
& Thalamus & 21 & 12.80 \\
& Brainstem & 15 & 9.15 \\
& Cerebellum & 8 & 4.88 \\
& Others & 4 & 2.44 \\
\hline
\end{tabular}

Source: Research data, processed

The smallest hematoma volume was $0.24 \mathrm{cc}$ that happened in basal ganglia area, while the largest hematoma volume was $138 \mathrm{cc}$ that happened in parietooccipital lobe. From this study, we found that most of the patients had hematoma volume less than $30 \mathrm{cc}$. Although $\mathrm{ICH}$ in young adults was dominated with hematoma volume less than $30 \mathrm{cc}$, there were 12 patients $(5.8 \%)$ with hematoma volume $\geq 60 \mathrm{cc}$. We also found that most patients had $\mathrm{ICH}$ located in basal ganglia, followed by lobar area (Table 2).

Hemorrhage located in lobar area could be further divided into each lobe, with parietal lobe as the area lobar $\mathrm{ICH}$ most often occurred. In this study, although less frequent, there were $\mathrm{ICH}$ that was located in periventricular area $(2.9 \%)$, pedunculus cerebri $(0.48 \%)$, and also in body corpus callosum $(0.48 \%)$.

We also found that if it was further divided into 3 age groups, there were different dominant locations of the $\mathrm{ICH}$ (Table 3). In younger group of age (younger than 36 years old), the location of ICH mostly occurred in lobar area. The trend was different in older group of age (36 to 45 years old), where most of the young adults $\mathrm{ICH}$ occurred in basal ganglia area. We also found that in 18 to 25 years old group, there was no $\mathrm{ICH}$ that occurred in the brainstem or thalamus area.

\section{Discussion}

In this study, there were two aspects of the CT scan imaging studied, which were hematoma volume and the location of $\mathrm{ICH}$.

\section{Hematoma Volume}

From all 207 young adults $\mathrm{ICH}$ patients, it could be seen that most patients had $\mathrm{ICH}$ with hematoma volume less than $30 \mathrm{cc}$. There were also only a small number of young adult patients with hematoma volume more than 60 cc. There were several other studies with similar findings that in young adult $\mathrm{ICH}$ patients, most had hematoma volume less than $30 \mathrm{cc}^{3,8}$ Lesser hematoma volume in younger patients than in older patients suggested that aging process was an important factor which caused larger hematoma volume in older patients. Aging process lead to changes in brain plasticity which resulted in weaker brain tissue. Therefore, the barrier that restricted the spreading of hematoma was lost in older patients, making lesser hematoma volume in younger $\mathrm{ICH}$ patients. ${ }^{9}$ The importance of knowing hematoma volume in $\mathrm{ICH}$ patients was to predict the patient's prognosis. A study by Panchal, et al. found that hematoma volume could be used as an easy instrument to assess the mortality of an $\mathrm{ICH}$ case within 30 days. Patients with hematoma volume more than $30 \mathrm{cc}$ had higher mortality rate rather than patients with smaller hematoma volume. ${ }^{10}$ Although, in another study, it was found that there was no significant effect caused by hematoma volume with the young $\mathrm{ICH}$ patient's prognosis. 3,11

\section{Location of Hemorrhage}

In this study, the location where $\mathrm{ICH}$ most often occurred was in basal ganglia area, then followed by lobar area, especially parietal lobe area. Although, if further inspected based on the age group, there was a different location trend between younger group (less than 36 years old) and older group (36 to 45 years old). In older group, basal ganglia was still the most often occurring location of $\mathrm{ICH}$, but in younger group, instead of basal ganglia, lobar $\mathrm{ICH}$ dominated this group of age. Studies regarding young adults $\mathrm{ICH}$ in China and also in Taiwan found the same pattern regarding this matter. ${ }^{7,} 10$ Ruiz-Sandoval, et al. in their study found that there were more patients with $\mathrm{ICH}$ located in lobar area rather than in basal ganglia area. ${ }^{12}$

$\mathrm{ICH}$ that occurred in basal ganglia area usually correlated to hypertension. Therefore, increase of $\mathrm{ICH}$ occurring in basal ganglia in young adult patients should be a matter of concern. Increasing pressure in Circle of Willis, which was located around basal ganglia area, caused by hypertension was correlated with $\mathrm{ICH}$ that occurred in basal ganglia area. ${ }^{13}$ Therefore, blood pressure controls in $\mathrm{ICH}$ cases that occurred in basal ganglia area became an important procedure. ICH patients whose blood pressure was controlled with INTERACT (Intensive Blood Pressure Reduction in Acute Cerebral Hemorrhage Trial) technique showed faster improvement in neurology function. With INTERACT technique, the expanding of hematoma volume and also the formation of peripheral edema could be inhibited. ${ }^{14}$

There were several conditions that could cause lobar $\mathrm{ICH}$, such as CAA (Cerebral amyloid angiopathy) that usually happened in older $\mathrm{ICH}$ patients, intracranial vascular malformations, brain tumors, cerebral venous thrombosis, hemorrhagic transformation, and other vasculopathies and systemic disease. ${ }^{15}$ In a study by Van 
Beijnum, et al., it found that among all $\mathrm{ICH}$ patients with AVM, around $73 \%$ had lobar $\mathrm{ICH}, 16 \%$ had $\mathrm{ICH}$ in infratentorial area, and $11 \%$ had deep $\mathrm{ICH} .{ }^{16}$

According to the findings in previous studies, $\mathrm{ICH}$ in 36 to 45 years old patients which occurred more frequently in basal ganglia found in this study could be related with hypertension. Meanwhile, lobar ICH which occurred more frequently in the less than 36 years old group of patients could suggest $\mathrm{ICH}$ in tis group were more related with vascular malformation and other diseases.

This study had several limitations. The source of the data in this study used the medical record in Dr. Soetomo General Hospital, Surabaya that was still a paper-based medical record. Therefore, some data could not be read clearly and there were also incomplete data. This condition could bring bias in the results of the study due to the exclusion of some data that did not meet the requirements. There was also a possibility of error in the data recorded in the medical record, and there was no means to cross check the reliability of the collected data.

Despite its limitation, this study obtained a large number of young adult $\mathrm{ICH}$ patients from quite a long period of time (4 years). Dr. Soetomo General Hospital, Surabaya where the study was conducted was also the biggest and one of the referral hospitals in East Indonesia. Thus, this study provides important information about the CT scan imaging trend of young adult $\mathrm{ICH}$ patients in Indonesia.

\section{Conclusion}

The CT scan imaging of young adults $\mathrm{ICH}$ mainly had hematoma volume less than $30 \mathrm{cc}$. Whereas for the location of $\mathrm{ICH}$, most young adults $\mathrm{ICH}$ occurred in basal ganglia area. Although, in younger group of age, most of $\mathrm{ICH}$ was lobar $\mathrm{ICH}$. The increased incidence of $\mathrm{ICH}$ occurred in basal ganglia in young adult patients which was related to hypertension indicated how important blood pressure control was in this case. Further analytic study regarding hypertension and its connection with the incidence of young adults $\mathrm{ICH}$ must be done in the future.

\section{CONFLICT OF INTEREST}

The author stated there is no conflict of interest in this study.

\section{REFERENCES}

1. Sacco RL, Kasner SE, Broderick JP, et al. An Updated Definition of Stroke for the 21st Century: A Statement for Healthcare Professionals from the American Heart Association/American Stroke Association. Stroke. 2013; 44: 2064-89.
2. Indonesia DKR. Pokok-Pokok Hasil Riskesdas Provinsi Jawa Timur Tahun 2013. Jakarta: Badan Penelitian dan Pengembangan Kesehatan, 2013.

3. Koivunen R-J, Haapaniemi E, Satopää J, Niemelä M, Tatlisumak T and Putaala J. Medical Acute Complications of Intracerebral Hemorrhage in Young Adults. Stroke Research and Treatment. 2015; 2015: 357696.

4. Magistris F, Bazak S and Martin J. Intracerebral Hemorrhage: Pathophysiology, Diagnosis and Management. McMaster University Medical Journal. 2013 10: $15-22$.

5. Caplan LR. Caplan's Stroke: A Clinical Approach. 5th ed. New York: Cambridge University Press, 2016.

6. Hemphill JC, Greenberg SM, Anderson CS, et al. Guidelines for the Management of Spontaneous Intracerebral Hemorrhage. Stroke. 2015; 46: 2032-60.

7. Aguilar $\mathrm{Ml}$ and Brott TG. Update in Intracerebral Hemorrhage. Neurohospitalist. 2011; 1: 148-59.

8. Zhou HX, Hao N and Xu XL. Related Factors of Early Mortality in Young Adults with Cerebral Hemorrhage. Open Med (Wars). 2018; 13: 214-20.

9. Ruiz-Sandoval JL, Romero-Vargas S, Chiquete E, et al. Hypertensive Intracerebral Hemorrhage in Young People: Previously Unnoticed Age-Related Clinical Differences. Stroke. 2006; 37: 2946-50.

10. Panchal HN, Shah MS and Shah DS. Intracerebral Hemorrhage Score and Volume as an Independent Predictor of Mortality in Primary Intracerebral Hemorrhage Patients. The Indian Journal of Surgery. 2015; 77: 302-4.

11. Lai SL, Chen ST, Lee TH, Ro LS and Hsu SP. Spontaneous Intracerebral Hemorrhage in Young Adults. European Journal of Neurology. 2005; 12: 310-6.

12. Ruíz-Sandoval JL, Cantú $C$ and Barinagarrementeria F. Intracerebral Hemorrhage in Young People. Stroke. 1999; 30: 537-41.

13. Sutherland GR and Auer RN. Primary Intracerebral Hemorrhage. Journal of Clinical Neuroscience : Official Journal of the Neurosurgical Society of Australasia. 2006; 13: $511-7$.

14. Gong FT, Yu LP, Gong YH, Zhang YX, Wang ZG and Yan CZ. Blood Pressure Control in Ultra-Early Basal Ganglia Intracerebral Hemorrhage. European Review for Medical and Pharmacological Sciences. 2015; 19: 412-5.

15. Domingues R, Rossi $C$ and Cordonnier C. Classification of Intracerebral Haemorrhages. European Neurological Review. 2015; 9: 129-35.

16. van Beijnum J, Lovelock CE, Cordonnier C, Rothwell PM, Klijn CJ and Al-Shahi Salman R. Outcome after Spontaneous and Arteriovenous Malformation-Related Intracerebral Haemorrhage: Population-Based Studies. Brain : A Journal of Neurology. 2009; 132: 537-43. 